\title{
The Potential for Energy Retrofits within the City of Sacramento's Rental Housing Inspection Program
}

MM Iverson

$S$ Sande

ML Britt

April 2011

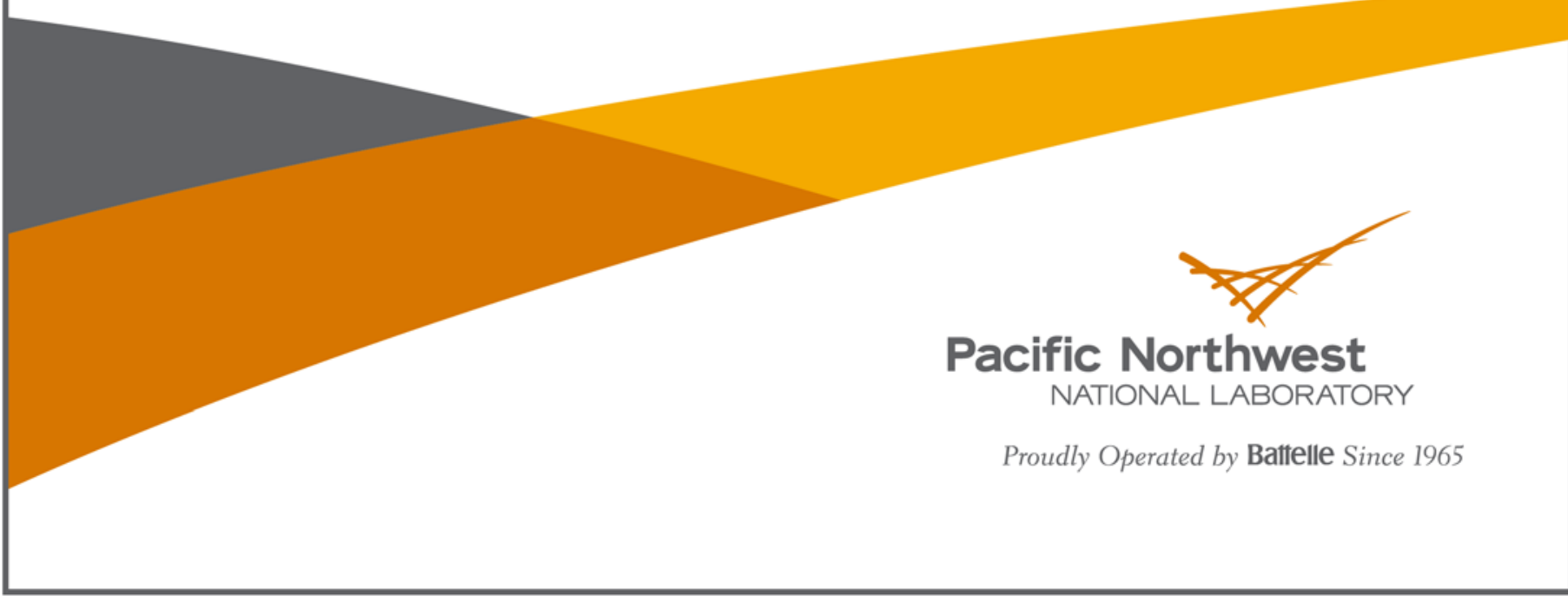




\title{
DISCLAIMER
}

This report was prepared as an account of work sponsored by an agency of the United States Government. Neither the United States Government nor any agency thereof, nor Battelle Memorial Institute, nor any of their employees, makes any warranty, express or implied, or assumes any legal liability or responsibility for the accuracy, completeness, or usefulness of any information, apparatus, product, or process disclosed, or represents that its use would not infringe privately owned rights. Reference herein to any specific commercial product, process, or service by trade name, trademark, manufacturer, or otherwise does not necessarily constitute or imply its endorsement, recommendation, or favoring by the United States Government or any agency thereof, or Battelle Memorial Institute. The views and opinions of authors expressed herein do not necessarily state or reflect those of the United States Government or any agency thereof.

\author{
PACIFIC NORTHWEST NATIONAL LABORATORY \\ operated by \\ BATTELLE \\ for the \\ UNITED STATES DEPARTMENT OF ENERGY
}

under Contract DE-AC05-76RL01830

Printed in the United States of America

$$
\begin{aligned}
& \text { Available to DOE and DOE contractors from the } \\
& \text { Office of Scientific and Technical Information, } \\
& \text { P.O. Box 62, Oak Ridge, TN 37831-0062; } \\
& \text { ph: (865) 576-8401 } \\
& \text { fax: (865) 576-5728 } \\
& \text { email: reports@adonis.osti.gov }
\end{aligned}
$$

\author{
Available to the public from the National Technical Information Service \\ 5301 Shawnee Rd., Alexandria, VA 22312 \\ ph: (800) 553-NTIS (6847) \\ email: orders@ntis.gov <http://www.ntis.gov/about/form.aspx> \\ Online ordering: http://www.ntis.gov
}




\title{
The Potential for Energy Retrofits within the City of Sacramento's Rental Housing Inspection Program
}

\author{
MM Iverson \\ S Sande \\ ML Britt
}

April 2011

Prepared for

the U.S. Department of Energy

under Contract DE-AC05-76RL01830

Pacific Northwest National Laboratory

Richland, Washington 99352 



\title{
Acronyms and Abbreviations
}

\author{
EER energy efficiency ratio \\ FTE full-time equivalent \\ HSPF heating seasonal performance factor \\ HVAC heating, ventilation, and air conditioning \\ PNNL Pacific Northwest National Laboratory \\ RHIP Rental Housing Inspection Program \\ SEER seasonal energy efficiency ratio \\ SMUD Sacramento Municipal Utility District \\ TAP Technical Assistance Program
}





\section{Contents}

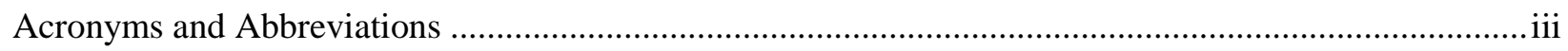

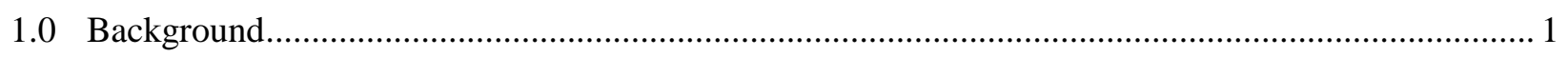

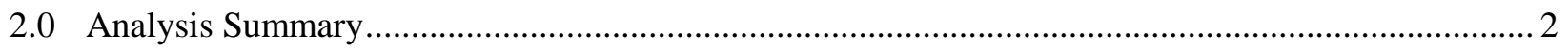

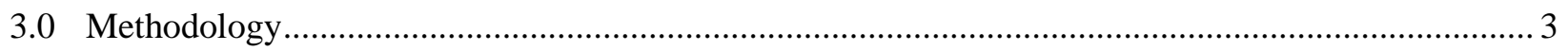

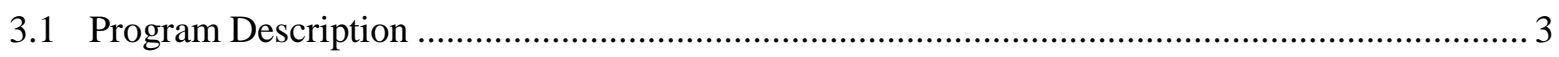

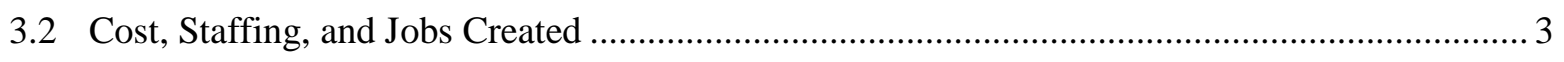

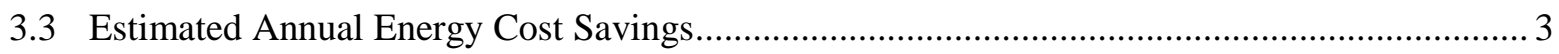

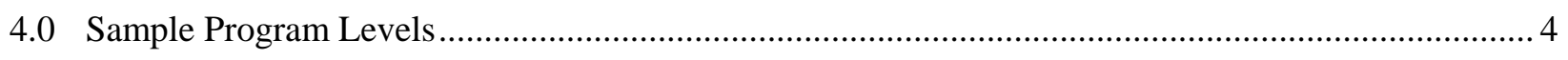

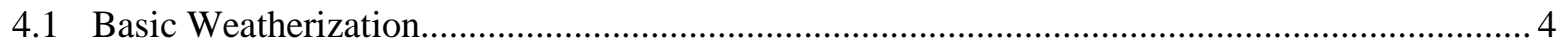

4.1.1 Program Cost, Staffing, and Jobs Created.................................................................. 4

4.1.2 Estimated Annual Energy Cost Savings..................................................................... 5

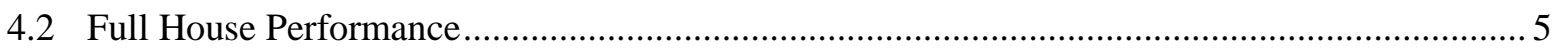

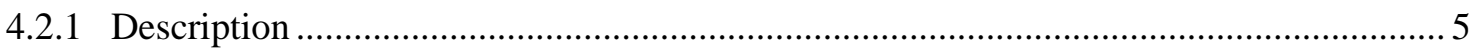

4.2.2 Program Cost, Staffing, and Jobs Created.............................................................. 6

4.2.3 Estimated Annual Energy Cost Savings....................................................................... 6

4.3 Full House Performance with Enhanced Options ............................................................... 7

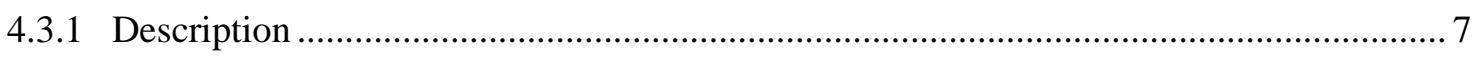

4.3.2 Program Cost, Staffing, and Jobs Created.................................................................. 7

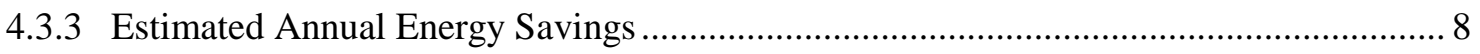

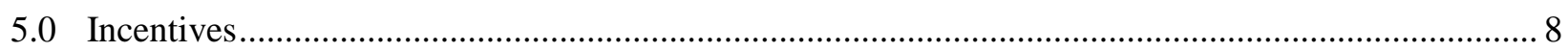

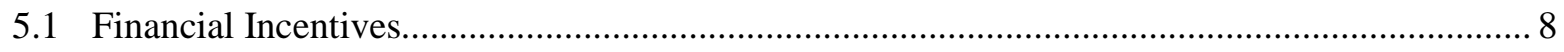

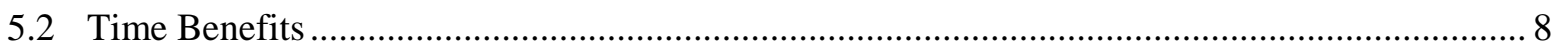

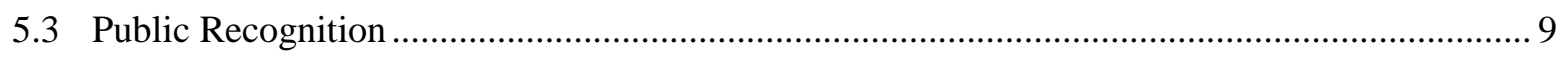

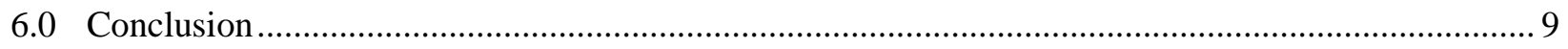

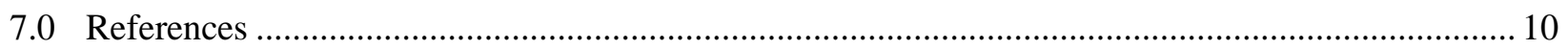




\section{Tables}

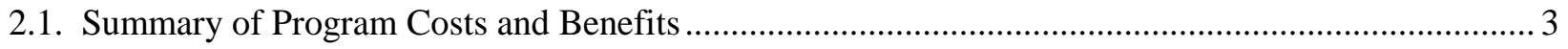

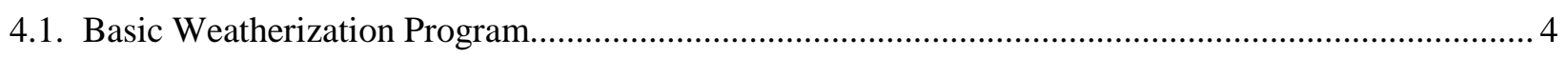

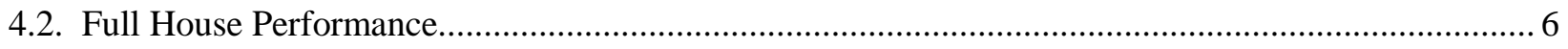

4.3. Full House Performance with Enhanced Options ........................................................................... 7 


\subsection{Background}

This report presents the results of an analysis performed by Pacific Northwest National Laboratory (PNNL) for the City of Sacramento- under the U.S. Department of Energy's Energy Efficiency and Renewable Energy Office of Weatherization and Intergovernmental Projects Technical Assistance Program (TAP) — to help determine the potential for incorporating energy efficiency standards into the City's existing Rental Housing Inspection Program (RHIP) as part of Sacramento's efforts to create a Climate Action Plan.

Under the current RHIP, the City inspects rental housing (both single family and multifamily) for blight, health, and safety only. All parcels with rental units are inspected within the first 5-year program cycle. The program is paid for by an annual assessment (\$28) on all rental units in Sacramento. The scope of this TAP effort was to help develop several program options as part of the Climate Action Plan, including a conceptual program(s) description, expected energy savings, program costs and fee increases, and benefits such as the potential for job creation and lower energy bills for occupants. Identifying potential incentives was also important.

Key factors identified by City staff that influence the potential effects of incorporating energy efficiency weatherization standards into the RHIP include: ${ }^{1}$

1. Split incentives: Rental housing is less likely to be retrofitted for energy savings than owner occupied housing. Landlords are less likely to invest in energy efficiency, not realizing the potential for increasing value to their property and not benefiting from reduced operating costs which are borne by the renters. Conversely, renters rarely invest in property they don't own. The result is housing that is less energy efficient.

2. High number of rentals: In 2010 , about 90,000 units, or $46 \%$ of Sacramento’s total housing, were rentals.

3. Older, inefficient housing stock: Sacramento's housing stock is relatively old. Approximately 65\% of housing units in the city were built before the advent of California's Title 24 Energy Efficiency Standards in 1978. Furthermore, many, if not most, of these are single family homes. Single family homes tend to be less energy efficient than multifamily dwelling units of similar size and age, due to the self-insulating effect of shared walls and ceilings in attached housing. Retrofitting older, less efficient housing offers a relatively high cost/benefit ratio when compared to other energy investments, such as investing in renewables.

4. Income-based need for reduced energy cost: Over half of the households in Sacramento are low income (19\% low income; 14\% very low income; 18\% extremely low income). Improving the energy efficiency of rental housing would likely save money for those who need it most.

5. Potential job creation: There is potential to create new jobs. The number of jobs created would depend on how many units are weatherized and the level of improvement required. Currently, the City inspects 18,000-20,000 rental units per year. 
The challenges identified by City staff include:

1. Funding for staff (mostly inspectors): The City has had several years of layoffs, and additional staff would be needed to implement weatherization inspection as part of the RHIP. The ideal program would be streamlined to minimize the number of new staff required.

2. Balanced program expansion: Balancing the need to create jobs, reduce energy costs for low income families, and meet the City's greenhouse reduction goals with the need to expand the RHIP program in a way that minimizes cost increases to rental property owners.

\subsection{Analysis Summary}

Three sample weatherization programs were identified for incorporation into the RHIP:

1. Basic weatherization - both voluntary and mandatory

2. Full house performance

3. Full house performance with enhanced options

PNNL assumed each program would require an inspection, or audit; and a determination would be made for each unit as to the appropriate weatherization measures. The market penetration rate assumptions are based on background information provided by the City regarding age of housing stock and effect of weatherization on typical housing stock as illustrated using the Sacramento Municipal Utility District (SMUD) Home Energy Calculator. ${ }^{2}$ The following metrics were developed for each program:

1. Program cost, staffing, and jobs created

2. Estimated annual energy cost savings

As illustrated in the comparison in Table 2.1, the mandatory basic weatherization shows the greatest potential when considering effect per full-time equivalent (FTE) of City staff. However, depending on market penetration rates, the voluntary basic weatherization may provide the same benefit ratio. The numbers below assume $1 \%-3 \%$ of those units in the RHIP would participate in the voluntary weatherization program. 
Table 2.1. Summary of Program Costs and Benefits

\begin{tabular}{|c|c|c|c|c|c|c|c|}
\hline & \multicolumn{2}{|c|}{$\begin{array}{l}\text { Voluntary Basic } \\
\text { Weatherization }\end{array}$} & \multirow{2}{*}{$\begin{array}{c}\begin{array}{c}\text { Mandatory } \\
\text { Basic }\end{array} \\
\text { Weatherization } \\
75 \%\end{array}$} & \multicolumn{2}{|c|}{$\begin{array}{c}\text { Voluntary Full House } \\
\text { Performance }\end{array}$} & \multicolumn{2}{|c|}{$\begin{array}{c}\text { Voluntary Full House } \\
\text { Performance with } \\
\text { Enhanced Options } \\
\end{array}$} \\
\hline $\begin{array}{l}\text { Market } \\
\text { Penetration }\end{array}$ & $1 \%$ & $3 \%$ & & $1 \%$ & $3 \%$ & $1 \%$ & $3 \%$ \\
\hline Percent Savings & $15 \%$ & $15 \%$ & $15 \%$ & $50 \%$ & $50 \%$ & $50 \%$ & $50 \%$ \\
\hline $\begin{array}{l}\text { kWh Savings } \\
\text { (per Unit) }\end{array}$ & $\begin{array}{c}854- \\
1500 \mathrm{kWh}\end{array}$ & $\begin{array}{c}854- \\
1500 \mathrm{kWh}\end{array}$ & $\begin{array}{c}854- \\
1500 \mathrm{kWh}\end{array}$ & $\begin{array}{c}1654- \\
2148 \mathrm{kWh}\end{array}$ & $\begin{array}{c}1654- \\
2148 \mathrm{kWh}\end{array}$ & $\begin{array}{c}1654- \\
2148 \mathrm{kWh}\end{array}$ & $\begin{array}{c}1654- \\
2148 \mathrm{kWh}\end{array}$ \\
\hline Staffing Needs & $0.5 \mathrm{FTE}$ & 1 FTE & 13 FTE & 1 FTE & $2.5 \mathrm{FTE}$ & 1 FTE & 2.5 FTE \\
\hline $\begin{array}{l}\text { Home } \\
\text { Weatherization/ } \\
\text { Retrofit Jobs }\end{array}$ & 3 FTE & $8 \mathrm{FTE}$ & 207 FTE & 16 FTE & 48 FTE & 20 FTE & 60 FTE \\
\hline $\begin{array}{l}\text { Estimated } \\
\text { Annual Energy } \\
\text { Cost Savings } \\
\text { per Household }\end{array}$ & $\$ 330-\$ 420$ & $\$ 330-\$ 420$ & $\$ 330-\$ 420$ & $\begin{array}{l}\$ 1100- \\
\$ 1400\end{array}$ & $\begin{array}{l}\$ 1100- \\
\$ 1400\end{array}$ & $\begin{array}{l}\$ 1100- \\
\$ 1400\end{array}$ & $\begin{array}{l}\$ 1100- \\
\$ 1400\end{array}$ \\
\hline $\begin{array}{l}\text { Potential } \\
\text { Annual } \\
\text { Citywide } \\
\text { Energy Cost } \\
\text { Savings }\end{array}$ & $\begin{array}{l}\$ 59,400- \\
\$ 75,600\end{array}$ & $\begin{array}{l}\$ 178,200- \\
\$ 226,800\end{array}$ & $\begin{array}{l}\$ 4.4-\$ 5.7 \\
\text { million }\end{array}$ & $\begin{array}{l}\$ 198,000- \\
\$ 252,000\end{array}$ & $\begin{array}{l}\$ 594,000- \\
\$ 756,000\end{array}$ & $\begin{array}{l}\$ 198,000- \\
\$ 252,000\end{array}$ & $\begin{array}{l}\$ 594,000- \\
\$ 756,000\end{array}$ \\
\hline $\begin{array}{l}\text { City-Wide } \\
\text { Savings per } \\
\text { Inspection Staff } \\
\text { FTE }\end{array}$ & $\begin{array}{l}\$ 118,800- \\
\$ 151,200\end{array}$ & $\begin{array}{l}\$ 178,200- \\
\$ 226,800\end{array}$ & $\begin{array}{l}\$ 338,000- \\
\$ 438,000\end{array}$ & $\begin{array}{l}\$ 198,000- \\
\$ 252,000\end{array}$ & $\begin{array}{l}\$ 237,600- \\
\$ 302,400\end{array}$ & $\begin{array}{l}\$ 198,000- \\
\$ 252,000\end{array}$ & $\begin{array}{l}\$ 237,600- \\
\$ 302,400\end{array}$ \\
\hline
\end{tabular}

\subsection{Methodology}

\subsection{Program Description}

Each of the four program descriptions was based on established weatherization programs, and SMUD programs were used as a local benchmark.

\subsection{Cost, Staffing, and Jobs Created}

Estimates for staffing needs and jobs created were based on typical durations associated with the varying levels of inspection, and then calculated based on anticipated market penetration to determine an approximate number of FTEs needed. Weatherization jobs were estimated based on typical hours per job, as provided by a major local contractor. ${ }^{3}$ Assumptions for the analysis of each program were documented in the analysis.

\subsection{Estimated Annual Energy Cost Savings}

The energy savings were calculated based on three typical rental units, estimates from SMUD's anticipated savings, and SMUD’s Home Energy Calculator. The utility savings include both gas and electricity. The typical rental units include two single family homes, circa 1950 and 1970, and an apartment, circa 1980. Savings were estimated based on input from a local contractor3, PNNL staff 
experience, coupled with SMUD and U.S. Environmental Protection Agency ENERGY STAR estimates ${ }^{4}$, and verified with SMUD’s calculator.

\subsection{Sample Program Levels}

\subsection{Basic Weatherization}

Under this basic weatherization program, the RHIP inspection would expand to look for opportunities to improve energy efficiency, such as adding insulation, weather-stripping, adding water heater blankets, and fixing leaky faucets. The inspection would be conducted visually and would not include home performance testing such as duct or blower door tests included in the options discussed in Sections 4.2 and 4.3. Table 4.1 identifies the elements of the voluntary basic weatherization program. This simple list of upgrades includes what are typically the most effective, least costly improvements and is consistent with the current SMUD basic list of upgrades. ${ }^{5}$ This program could be either voluntary or mandatory; analysis has been provided to illustrate potential costs and benefits under both scenarios.

Table 4.1. Basic Weatherization Program

\begin{tabular}{ll}
\hline \multicolumn{1}{c}{ Area } & \multicolumn{1}{c}{ Recommended Standard } \\
\hline Attics and Ceilings & $\begin{array}{l}\text { Insulate to R-38 } \\
\text { Air seal attic }\end{array}$ \\
Ducts (in unconditioned areas such as attics) & $\begin{array}{l}\text { Insulate with R-6 } \\
\text { Seal duct leaks }\end{array}$ \\
Exterior Doors & Install insulated exterior door (U-0.40) \\
Whole House & Weather-strip and caulk \\
Water Heater (in unconditioned areas such as garages) & $\begin{array}{l}\text { Insulate to minimum R-12 } \\
\text { Reduce water heater set points to at least } 120^{\circ} \mathrm{F}\end{array}$ \\
Install medium-colored draperies with white thermal backings to \\
Draperies
\end{tabular}

\subsubsection{Program Cost, Staffing, and Jobs Created}

Expanding the current RHIP inspection to include basic weatherization audits is estimated to add 2 hours to each inspection.

\subsubsection{Voluntary Implementation}

As a voluntary addition to the RHIP, the basic weatherization program would have an estimated market penetration of $1 \%-3 \%$. Adding 2 hours to $1 \%-3 \%$ of the current 18,000 annual inspections equates to an additional 360-1080 labor hours. Assuming 2080 hours per year, this equates to approximately one-half to one annual FTEs of inspection staff. Local contractors estimate 32 hours of labor per home on basic weatherization. This equates to 3-8 FTEs of local weatherization jobs. 


\subsubsection{Mandatory Implementation}

As a mandatory addition to the RHIP, the basic weatherization program would increase $75 \%$ of all 18,000 annual inspections by 2 hours each, which equates to an additional 27,000 labor hours. Assuming 2080 hours per year, this equates to approximately 13 annual FTEs of inspection staff. It also equates to 207 FTEs of home weatherization jobs.

\subsubsection{Estimated Annual Energy Cost Savings}

Based on the typical age and construction features of the current rental housing stock and estimates from the Energy Upgrade California program ${ }^{6}$, and using SMUD’s Home Energy Savings calculator, an average 15\% estimated annual energy cost savings is estimated, resulting in an annual savings of \$330\$420 per household annual assuming a typical current utility cost of \$2200-\$2800.

\subsubsection{Voluntary Implementation}

Again assuming a market penetration of $1 \%-3 \%$, voluntary implementation of basic weatherization would save between $\$ 118,800$ and $\$ 226,800$ in utility costs annually across the city. This would decrease demand on local utilities and provide utility payers with money that could be saved or spent elsewhere.

\subsubsection{Mandatory Implementation}

Assuming a market penetration of 75\%, mandatory implementation of basic weatherization would save between $\$ 338,000$ and $\$ 438,000$ in utility costs annually across the city. This would decrease demand on local utilities and provide utility payers with money that could be saved or spent elsewhere.

\subsection{Full House Performance}

\subsubsection{Description}

The full house performance program builds on the basic weatherization features in Table 4.1, and includes additional prescriptive improvements and home testing. Table 4.2 identifies the elements of the voluntary comprehensive performance-based weatherization program. This list is consistent with typical performance audits, including the State of Oregon's guidance ${ }^{7}$ and the current SMUD list of comprehensive performance upgrades.5 Because of the more comprehensive nature of this program, the analysis assumes it would only be proposed as a voluntary program, and market penetration rates reflect that assumption. 
Table 4.2. Full House Performance

\begin{tabular}{|c|c|}
\hline Area & Recommended Standard \\
\hline Attics and Ceilings & Insulate to R-38 \\
\hline \multicolumn{2}{|l|}{ Walls } \\
\hline Outside walls & Insulate to achieve R-19 \\
\hline Attic exposed wall & Insulate to R-38 \\
\hline Floors & Insulate to R-19 \\
\hline Ducts (in unconditioned areas such as attics) & $\begin{array}{l}\text { Insulate with R-6 } \\
\text { Seal duct leaks }\end{array}$ \\
\hline Exterior Doors & Install insulated exterior door (U-0.40) \\
\hline Windows & $\begin{array}{l}\text { Install energy efficient double-pane vinyl windows (U- } 0.40 \text { or } \\
\text { better) }\end{array}$ \\
\hline Whole House & Weather-strip and caulk, lower the set point a few degrees \\
\hline Water Heater (in unconditioned areas such as garages) & Insulate to minimum R-12 \\
\hline Heating, Ventilation, and Air Conditioning (HVAC) & $\begin{array}{l}\text { Replace the existing heating and cooling system with a high } \\
\text { efficiency system. The minimum recommended levels of } \\
\text { efficiency include seasonal energy efficiency ratio (SEER) 16, } \\
\text { energy efficiency ratio (EER) split system 14.5, heating seasonal } \\
\text { performance factor (HSPF) 8.5, as applicable. }\end{array}$ \\
\hline Programmable Thermostat & $\begin{array}{l}\text { Install a programmable thermostat; lower the set point to } 68^{\circ} \mathrm{F} \text { for } \\
\text { heating and } 78^{\circ} \mathrm{F} \text { for cooling }\end{array}$ \\
\hline Light Bulbs & Change out light bulbs to be compact fluorescent \\
\hline Performance Testing & Perform blower door test and enhanced building envelope sealing \\
\hline
\end{tabular}

\subsubsection{Program Cost, Staffing, and Jobs Created}

Based on PNNL staff field experience and estimates from contractors, full audits, including documentation, take 8-12 hours. Because of the more comprehensive nature of the audits and potential costs for improvements, PNNL assumes a market penetration rate of 1\%-3\%. Adding 10 hours to $1 \%-$ $3 \%$ of the current 18,000 annual inspections equates to an additional 1800-5400 labor hours. Assuming 2080 hours per year, this equates to approximately 1-2.5 annual FTEs of inspection staff. Local contractors estimate 184 hours per home on a full house performance retrofit. This equates to 16-48 FTEs of local weatherization jobs.

\subsubsection{Estimated Annual Energy Cost Savings}

Based on the typical age and construction features of the current rental housing stock, and using SMUD's weatherization savings calculator, an average $50 \%$ savings is estimated, resulting in an annual savings of \$1100-\$1400 per household, assuming typical annual current utility cost of \$2200-\$2800.

Again assuming a market penetration of 1\%-3\%, full house performance would save between $\$ 198,000$ and $\$ 756,000$ in utility costs annually across the city. This would decrease demand on local utilities and provide utility payers with money that could be saved or spent elsewhere. 


\subsection{Full House Performance with Enhanced Options}

\subsubsection{Description}

The full house performance with enhanced options program includes the basic weatherization features in Table 4.1 and the additional prescriptive improvements and home testing in Table 4.2, and adds enhanced options of GreenPoint third party verification and labeling, onsite power generation, and water conserving landscaping, as shown in Table 4.3. The enhanced options are more fully described on the Energy Upgrade California website. ${ }^{8}$

Table 4.3. Full House Performance with Enhanced Options

\begin{tabular}{|c|c|}
\hline Area & Recommended Standard \\
\hline Attics and Ceilings & Insulate to R-38 \\
\hline \multicolumn{2}{|l|}{ Walls } \\
\hline Outside walls & Insulate to achieve R-13 \\
\hline Attic exposed wall & Insulate to R-21 \\
\hline Floors (crawl spaces) & Insulate to R-30 \\
\hline Ducts (in unheated areas) & $\begin{array}{l}\text { Insulate with R-8 } \\
\text { Seal duct leaks }\end{array}$ \\
\hline Exterior Doors & Install insulated exterior door (U-0.20) \\
\hline Windows & Install energy efficient double-pane vinyl windows (U-0.35 or better) \\
\hline Whole House & Weather-strip and caulk, lower the set point a few degrees \\
\hline Water Heater (unheated areas) & Insulated to minimum R-3 \\
\hline HVAC & $\begin{array}{l}\text { Replace the existing heating and cooling system with a high efficiency system. The } \\
\text { minimum recommended levels of efficiency include SEER 16, EER split system 14.5, } \\
\text { HSPF 8.5, as applicable. }\end{array}$ \\
\hline Programmable Thermostat & $\begin{array}{l}\text { Install a programmable thermostat; lower the set point to } 68^{\circ} \mathrm{F} \text { for heating and } 78^{\circ} \mathrm{F} \text { for } \\
\text { cooling }\end{array}$ \\
\hline Light Bulbs & Change out light bulbs to be compact fluorescent \\
\hline Performance Testing & Perform blower door test and duct sealing \\
\hline Green Upgrade & GreenPoint Rated label \\
\hline Renewable Energy & $\begin{array}{l}\text { Solar power } \\
\text { Geothermal heat pump }\end{array}$ \\
\hline Water Efficient Landscaping & $\begin{array}{l}\text { Smart irrigation } \\
\text { Lawn conversion } \\
\text { Rainwater catchment systems }\end{array}$ \\
\hline
\end{tabular}

\subsubsection{Program Cost, Staffing, and Jobs Created}

Based on PNNL staff field experience and estimates from contractors, full audits, including documentation, take 8-12 hours. Because of the more comprehensive nature of the audits and potential costs for improvements, PNNL assumes a market penetration rate of 1\%-3\%. Adding 10 hours to 1\%$3 \%$ of the current 18,000 annual inspections equates to an additional $1800-5400$ labor hours. Assuming 2080 hours per year, this equates to approximately 1-2.5 annual FTEs of inspection staff. Assuming 25\% additional local contractor labor for the enhanced options (230 hours per home) results in 20-60 additional FTEs of weatherization jobs. Additional costs may be incurred by the property owner for third party verifications, or certifications. 


\subsubsection{Estimated Annual Energy Savings}

Full house performance with enhanced options is not assumed to provide greater estimated annual energy cost savings than full house performance alone. Measuring the complete effects associated with added options such as GreenPoints and the benefits of onsite power generation involves many variables and is beyond the scope of this analysis.

Again assuming a market penetration of $1 \%-3 \%$, full house performance with enhanced options would save between $\$ 198,000$ and 756,000 in utility costs annually across the city. This would decrease demand on local utilities and provide utility payers with money that could be saved or spent elsewhere.

\subsection{Incentives}

Incentives can include financial compensation, time benefits, and public recognition.

\subsection{Financial Incentives}

Local incentives are currently available for individual elements of weatherization, including the following. ${ }^{9}$ Information on any future incentives is not available.

- Duct sealing: $\$ 300$

- Central air conditioner: \$400-\$1100 depending on efficiency of replacement unit

- Clothes washer replacement: \$35-\$125 depending on efficiency of replacement unit

- Cool roof: \$0.10-\$0.20 per square foot

- Dishwasher: \$30-\$50, depending on efficiency of replacement unit

- Heat pump: \$400-\$500, depending on efficiency of replacement unit

- Refrigerator recycling: \$35 room air conditioner: \$50

- Solar water heating: $\$ 500-\$ 1500$ depending on efficiency of replacement unit

- Whole house fan: $\$ 100$

Local incentives of up to $\$ 5000$ are also currently available through SMUD’s Home Performance Program.9

While the SMUD rebates do not cover the enhanced options, other incentives are available, including California Solar Initiative incentives. ${ }^{10}$

\subsection{Time Benefits}

Some may consider the permitting process to be too time-consuming and expensive. The Sacramento Green Building Task Force recommendations include a discount in fees for buildings that qualify as a green building. To address this, jurisdictions can establish a discounted fee and "fast track" for permitting 
desired weatherization and energy efficiency and conservation projects. For a list of California jurisdictions with these mechanisms, see the National Listing of Above Code, High Performance, and Green Building Programs. ${ }^{11}$

\subsection{Public Recognition}

Publicity increases consumer awareness, helps create a market for energy efficient building, and ultimately helps to transform development patterns and methods. Property owners need to know they are following a program that consumers want. The Sacramento Green Building Task Force recommended that local developers and project certifications be celebrated at city council/board meetings and other public meetings to help raise awareness. Effective publicity by the jurisdictions and property owners can both teach the public about the benefits of the program and create a stronger market for energy efficient rental properties. Jurisdictions can raise the profile of energy efficient rentals by publicly applauding the efforts of retrofitters through strategies such as a press release, a ribbon cutting with the mayor, prominent signage, or subsidized marketing through their websites.

Programs such as the RHIP that require builders to register as program participants provide a mechanism for marketing the property owner, and a way to follow-up in other areas. ${ }^{\mathrm{a}}, 12$

Of course, third party verification with ENERGY STAR or GreenPoint Rated Label ${ }^{13}$ also provides tools for public recognition.

\subsection{Conclusion}

Based on the analysis and all assumptions as described, the basic weatherization program shows the greatest potential for city-wide energy savings per RHIP inspection staff FTE. Although full house performance provides much greater energy savings per home, the number of FTEs needed to implement full house performance is much greater and the program has a lower assumed market penetration rate, providing less impact city-wide.

\footnotetext{
${ }^{\mathrm{a}}$ This discussion on public recognition as an incentive is based on the Southwest Energy Efficient Project 2008 report Going Beyond Code: A Guide to Creating Energy Efficient and Sustainable Buildings in the Southwest. For a complete discussion on incentives, please see Chapter 3, Developing an Effective Beyond Code Program.
} 


\subsection{References}

1. Selph, H. 2011. E-mail to Alexander Dane, National Renewable Energy Laboratory, from Helen Selph, City of Sacramento Community Development Department. February 15, 2011.

2. SMUD - Sacramento Municipal Utility District. Home Energy Calculator. Accessed April 11, 2011 at http://smud.apogee.net/homesuite/calcs/rescalc/default_supp.aspx (undated webpage).

3. Horbaly, B. 2011. E-Mail to Megan Iverson, Pacific Northwest National Laboratory, from Bill Horbaly, Bonney Plumbing, Heating, and Air. April 12, 2011.

4. EPA - U.S. Environmental Protection Agency. What to Expect from Home Performance with ENERGY STAR. Accessed April 4, 2011 at

http://www.energystar.gov/index.cfm?c=home_improvement.hm_improvement_hpwes_common (undated webpage).

5. SMUD - Sacramento Municipal Utility District. Home Energy Contractor Energy Assessment. Accessed April 4, 2011 at http://hpp.smud.org/index.php/homeowner/home-energy-contractorenergy-assessment (undated webpage).

6. CEC - California Energy Commission. Energy Upgrade California. Accessed April 7, 2011 at https://energyupgradeca.org/overview (undated webpage).

7. ODOE - Oregon Department of Energy. ODOE: Residential Customers. Accessed April 8, 2011 at http://www.oregon.gov/ENERGY/RESIDENTIAL/index.shtml (undated webpage).

8. CEC - California Energy Commission. Energy Upgrade California, Sacramento County, Enhanced Options. Accessed April 7, 2011 at

https://energyupgradeca.org/county/sacramento/about_enhancements (undated webpage).

9. SMUD - Sacramento Municipal Utility District. Promotions, rebates and financing. Accessed April 14, 2011 at http://www.smud.org/en/rebates/Pages/index.aspx (undated webpage).

10. State of California, California Energy Commission and California Public Utilities Commission. Consumer Contacts for Go Solar California. Accessed April 8, 2011 at http://www.gosolarcalifornia.ca.gov/contacts/consumers.php (undated webpage).

11. OCEAN - Online Code Environment \& Advocacy Network. National Listing of Above Code, High Performance, and Green Building Programs. Accessed April 9, 2011 at http://bcapocean.org/resource/national-listing-above-code-high-performance-and-green-building-programs (undated webpage).

12. Dunn, S, M Britt, and E Makela. 2008. Going Beyond Code: A Guide to Creating Energy Efficient and Sustainable Buildings in the Southwest. Southwest Energy Efficient Project, Boulder, CO.

13. Build It Green. Go for the Green Upgrade. Accessed April 8, 2011 at http://builditgreen.org/euc/ (undated webpage). 



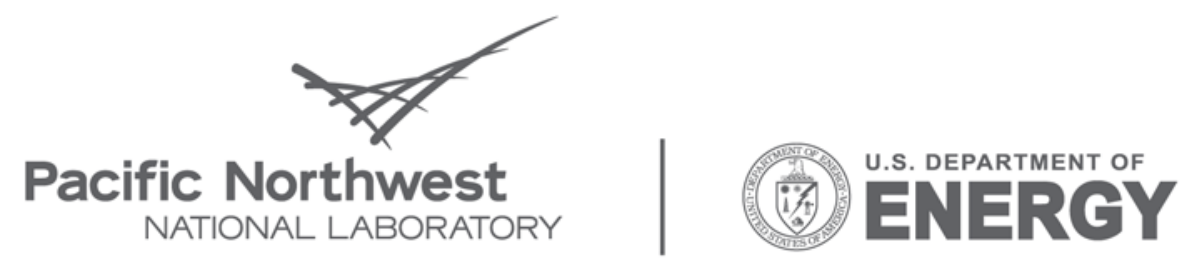

Proudly Operated by Battelle Since 1965

902 Battelle Boulevard

P.O. Box 999

Richland, WA 99352

1-888-375-PNNL (7665)

www.pnl.gov 